\title{
Fake News, Something New?
}

\author{
Ion Stavre ${ }^{1, *}$, Mònica Puntí ${ }^{2}$ \\ ${ }^{1}$ Department of Public Relations, College of Communication and Public Relations, National University of Political Studies and Public \\ Administration, Romania \\ ${ }^{2}$ Department of Philology and Communication, University of Girona, Spain
}

Copyright $\bigcirc 2019$ by authors, all rights reserved. Authors agree that this article remains permanently open access under the terms of the Creative Commons Attribution License 4.0 International License

\begin{abstract}
The purpose of this article is to discuss whether the phenomenon of 'fake news' is a new concept that has arisen with the emergence of information and communication technologies or is a previous term that has taken more force recently. First of all, in order to achieve this purpose, a definition of fake news is sought through a review of the existing literature on this topic. Secondly, a brief historical note is made about the phenomenon that serves as an introduction to the case studies that are explained in the present article. The investigation of the fake news phenomenon is analysed in the case studies in two different countries, Romania and Spain, and specific cases of each of them are explained. Finally, a brief reflection on the Internet, fake news and the new generations is made. The article concludes with some recommendations to deal with fake news such as promoting legal measures, returning to the basic values of journalism or collaboration between different institutions to achieve a better informed world.
\end{abstract}

Keywords Fake News, Mass Media, Social Networks, Television, Election Campaign, Disinformation

\section{Introduction}

Even if the "fake news" phenomenon appeared along with the press, as we will prove in this article, the digital era established this phenomenon permanently. We can identify a few reasons why "fake news" is spreading online so easily, through social networks. After 1990, the news broadcast by mainstream media, the important information for the readers, which helped them to orient themselves in daily life and to make their own decisions, has started to disappear. Step by step, the information made room for news about minor facts or for gossip news entertainment. In these circumstances, for the ordinary man, the emergence on the social networks of some obviously needed information was welcome. But, at the same time, this necessity represents also a major weakness, as the information provided by social networks is more difficult to check. The possibility for the social networks to store the users' personal data as psychological profile provided an exceptional work tool for those who wanted to manipulate the people's decisions.

The advent of the fake news phenomenon is favoured by the fact that the mass media presents two contradictory characteristics: the general function to inform and the business function. If both functions are balanced, then we can talk about a society with a solid, healthy democracy. The classic definition of a democratic society includes the existence of the market economy, multiparty and freedom of the press. If the business function is predominant in the mass media, then we can observe what is happening today. The fake news phenomenon has become a subject of prolonged hearings in the American Congress; funds have been allocated for the research of this phenomenon and for finding some solutions to reduce the consequences at the Western society level. After the Cambridge Analytica affair, Facebook changed its algorithms in order to avoid similar situations in the future. Even so, if we look clearly at the present time, we will observe an aspect that depends on a new technological revolution, the digital revolution: we are at the beginning of the competition between the digital authoritarianism and the liberal democracy:

"Some countries are already moving in this direction. China has begun to construct a digital authoritarian state by using surveillance and machine learning tools to control restive populations, and by creating what it calls a 'social credit system'. Several like-minded countries have begun to buy or emulate Chinese systems. Just as competition between liberal democratic, fascist, and communist social systems defined much of the twentieth century, so the struggle between liberal democracy and digital authoritarianism is set to define the twenty-first"'(Wright N. 2018).

An ultra tech society seems to be inevitably a society in which the control over the individual is much bigger. This control is not necessarily exerted by the state; it can be exerted also by private structures, for private interests. The interest for profit is so big that the punctual decisions for 
maximizing the profit can cause negative, long-term social phenomena. Such an example is the open letter signed by fifty American sociologists. The letter said: "Social media giants are employing 'unethical' psychologists to keep children hooked online for hours on end" (Wright M. 2018). The fake news phenomenon manifested in the political field has appeared out of the limitless desire to maximize the political profit and to win the elections. The result is the disinformation of the public that can no longer decide on the basis of real information.

After the dissolution of the Soviet Union, there has been observed a more and more increased admixture between the civil and the military practices of governance, especially in the former communist countries. The phenomenon is not negligible not even in the Western countries, including the United States. A report showed that "in the very near term, it will become more difficult, if not impossible, to distinguish between real and falsified audio, video, or online personalities. Malicious actors will use these technologies to target Western societies more rapidly and efficiently". (Polyakova and Boyer 2018)

\section{Definition of Fake News}

The field of communication has focused the attention in recent years on the phenomenon of fake news. That term is used to refer to openly false information that has no basis in true fact and which can be refuted using very basic checking mechanisms (Bounegru, Gray, Venturini and Mauri 2017). Although they have accompanied journalism since its inception, they have been spurred by the current existence of multiple news broadcasters. This kind of stories plays with credibility and appearance and relies on the public's tacit trust in the media. In addition, takes advantage of the fast replication through the Internet:

"Fake news is not just 'false news'. They are interesting not so much because their content or form are different from that of 'authentic news', but because they travel as much as (and sometimes more than) mainstream news. If a blog claims that Pope Francis endorses Donald Trump, it's just a lie. If the story is picked up by dozens of other blogs, retransmitted by hundreds of websites, cross-posted over thousands of social media accounts and read by hundreds of thousands, then it becomes fake news" (Bounegru, Gray, Venturini and Mauri 2017).

However, the use of the term "fake news" is widely discussed. Researchers like Claire Wardle, Ethan Zuckerman, danahboyd and Caroline Jack and journalists like the Washington Post's Margaret Sullivan have argued that the term is woefully inadequate to describe the complex phenomena of misinformation and disinformation (Wardle and Derakhshan 2017). In addition, has begun to be appropriated by politicians around the world who describe news organisations whose coverage they find disagreeable. Therefore it's becoming a mechanism by which the powerful can clamp down upon, restrict, undermine and circumvent the free press.

Wardle and Derakhshan, whose investigation about fake news has been published as a Council of Europe report, stand for a new conceptual framework for examining information disorder, identifying three types: misinformation, when false information is shared, but no harm is meant; disinformation, when false information is knowingly shared to cause hard, and mal-information, when genuine information is shared to cause harm, often by moving information designed to stay private into the public sphere.

Assuming that fake news is one of mechanisms through which post-truth is constructed, we can differentiate two goals for publishing disinformation. On one hand, the aim is to grab the user's attention, generate a click and produce a profit in the form of advertising impact, using the click-bait technique in order to get the audience's attention. On the other hand, there are post-truths that, without giving up the aim of achieving a large audience share, also want to become part of the collective discourse and narrative of facts, distorting reality and making it difficult to take a decision in favour or a particular political or economic interest (Kuklinski, Quirk, Jerit, Schwieder and Rich 2000).

The use of disinformation in creating strategic narratives has led the European Union to sort them as a threat to democracy (European Commission 2017). As Wardle and Derakhshan (2017) state, Western democracies are worried about how, in a diverse global media system, potential rivals like ISIS and Russia can use disinformation to further expand their reach into legislative and executive branches of power. The shock of the Brexit referendum, the US election and Le Pen reaching the run-off vote in the French election have been used as examples of the potential power of systematic disinformation campaigns. However, empirical data about the exact influence of such campaigns does not exist.

One of the events of recent years that have attracted most attention was the 2016 American presidential election won by Donald Trump. Those who had not considered the possibility of a Trump wanted simple explanations, and the idea that fabricated news sited could provide those explanations opened an intense discussion. The media editor for BuzzFeed News Craig Silverman offered evidence that the most popular of these fabricated stories where shared more widely than the most popular stories from the mainstream media.

"In the final three months of the US presidential campaign, 20 top-performing false election stories from hoax sites and hyper-partisan blogs generated 8.711 .000 shares, reactions, and comments on Facebook. Within the same time period, the 20 best-performing election stories from 19 major news websites generated a total of 7.367.000 shares, reactions, and comments on Facebook" (Silverman 2016). 
Disinformation aiming to establish a certain discourse appears within a context of conflict in order to impose an explanatory framework, and its purpose is to influence public opinion. This is accentuated in the case of issues where opinions are highly polarised (van der Linden, Leiserowitz, Rosenthal and Maibach 2017). While much of the contemporary furor about mis-information has focused on its political varieties, it contaminates public discourse on a range of issues such as health and climate change. Medical misinformation has always posed a worldwide threat to health, and research has demonstrated how incorrect treatment advice is perpetuated through spoken rumours, tweets, Google results and Pinterest boards. Furthermore, in the realm of climate change, a recent study examined the impact of exposure to climate-related conspiracy theories. It found that exposure to such theories created a sense of powerlessness, resulting in disengagement from politics and a reduced likelihood of people to make small changes that would reduce their carbon footprint.

The extent to which disinformation is accepted in such polarised contexts is related to the amplification by social media of fake news and post-truths. In the propagation of these pieces of information, the discursive framework proposed coinciding with the receiver's ideology becomes a determining factor in the consumption of disinformation (Allcott and Gentzkow 2017).

The success of fake news has been demonstrated in the investigation "The spread of true and false news online", carried out by the Massachusetts Institute of Technology (MIT) and published in March 2018 in Science Magazine. This research concludes that these stories are disseminated faster than true ones because they are more attractive than objective and contrasted facts. MIT analyzed 126.000 stories distributed on Twitter from 2006 to 2017 tweeted by around 3 million people more than 4.5 million times. Researchers underline that fake news is better narrated and more original than real, and triggers a more intense emotional response than a normal tweet. That is why they have a $70 \%$ more chance of being replicated.

"Falsehood diffused significantly farther, faster, deeper, and more broadly than the truth in all categories of information, and the effects were more pronounced for false news about terrorism, natural disasters, science, urban legends, or financial information" (Vosoughi, Roy and Aral 2018).

The emergence of the Internet and social media play a crucial role in the dissemination of information. Nowadays is easier than ever to create and distribute content, its consumption has become public because of social media, and information is passed in real-time between trusted peers, so any piece is far less likely to be challenged. Another critical point is that popular social networks make it difficult for people to judge the credibility of any message, because posts from publications as unlike as The New York Times and a conspiracy site look nearly identical.
This means that people are increasingly reliant on friends and family members to guide them through the information ecosystem.

The role of television in spreading all this stories must be also taken into account, argue researchers such as Wardle and Derakhshan. The focus on fabricated news sites means the implications of misleading, manipulated or fabricated visual content, whether that's an image, a visualization, a graphic, or a video are rarely considered. Visuals can be far more persuasive than other forms of communication, which can make them much more powerful vehicles for mis- and disinformation.

\section{A Brief History}

Fake news appeared with the press. One of the first examples of fake news is the one in which the New York Sun daily newspaper was involved. In 1835, the British astronomer John Herschel was making observations in South Africa by using a telescope directed at the Moon. In the New York Sun daily newspaper there were shown several stories about the fantastic images observed on the Moon, which were, in fact, a practical joke. After the publication of the first story, the number of sold copies increased from 8000 to 19000 , exceeding The Times newspaper in London. The fantastic reports were written by Richard Adams Locke, editor at the New York Sun. He knew that his farce would hardly be discovered, because the only means of communication, at that time, between New York and South Africa were the letters. But the farce was effective. After the publication of the stories related to the observations about the Moon, the New York Sun became the daily newspaper with the highest circulation (Standage 2017).

Even if the "fake news" term is new in the current usage, in the news practice the use of fake news is almost as old as journalism itself. Other examples of fake news are given by Cincinnati Commercial Tribune (Cincinnati, OH), 7 Jun. 1890 and by Impartial Observer (Richmond, VA), 9 May 1807 (Merriam-Webster 2018).

Fake news has even contributed to change the course of history. In 1898 social networks did not exist, but the newspapers were already fighting for the audience. In the last decade of the 19th century the term yellow press was coined to define the sensational journalism that kept New York World, ruled by Joseph Pulitzer, and New York Journal, from William Randolph Hearst. What nowadays would be considered fake news allowed EEUU to declare war against Spain in Cuba, which stopped being a Spanish colony after some months of armed conflict. Hearst blamed Spain for the explosion of the US battleship Maine in the port of Havana despite not being true. "Destruction of the war ship Maine was the work of an enemy", wrote New York Journal as the first headline of the front page, and added: "Naval officers think the Maine was destroyed by a Spanish mine". The text was accompanied with a drawing 
of the alleged attack.

In the USA, the "fake news" term has been associated for a long time with the political satire programs. Today, the term is essentially associated with disinformation.

\section{Mass Media in Romania after 1989}

The mass media in Romania has started in 1989 with 2 hours of broadcasting of the public television and a few central daily newspapers and has reached today over 300 radio and televisions licenses and daily newspapers. After 1997, as an editor-in-chief at the public television news department, I observed a few trends in the Romanian mass media, which led to the continuous decrease of the audience market share of the television channels.

Firstly, I observed a continuous decrease of the information content of the news and its transformation more and more into entertainment. The infotainment has rapidly installed itself, which led to emptying the information in the news bulletins. The pieces of information that concerned companies were considered forms of advertising and thus they were eliminated under the excuse that they were disguised ads. In fact, it was a disguised plea from the companies for advertising that generated those events that normally would represent the subject for regular news.

The second tendency that now characterizes the Romanian media and that began to manifest itself strongly after 1989 is the fusion between the information and the commentary. This phenomenon is so extended that it became a model for all the television channels in Romania. Jean François Revel has a memorable statement for the necessity to separate the journalistic components: the information is sacred; the commentary is free (Revel 1993). This fusion of the information with the commentary had a major consequence on the media market in Romania: the massive politicization of the televisions and the support of the partisanship, without shades. The situation is not unique, the media market being, in general, more and more politicized. Even in the United States, it is well-known that $\mathrm{CNN}$ is a television channel close to the American Democrat Party (after the election of Donald Trump this has been very noticeable), and Fox News is a television channel very close to the Republican Party.

In this moment, in Romania the news market is divided as follows: Antena 3 and Romania TV are news channels that support the Social Democratic Party, thus they support the political left, while Digi24, B1 TV and Realitatea TV support the National Liberal Party and, in general, the right side of the political spectrum.

The disappearance of informational content of the news and the polarization of the televisions are phenomena that have essentially contributed to the young people's attitude to distance themselves from the traditional television. They started to watch the news on the Internet, and Facebook became an important source of information. The televisions have noticed this phenomenon and started to broadcast different shows on Facebook. Such is the case of the Romanian public television.

The development of digital technology led to fundamental transformations of the mass media in Romania that diminished the journalists' historical stages of professional evolution. Until the fall of communism, the mass media and particularly the public television had been dominated by propaganda. After the fall of communism, in 1989 , the mass media in Romania entered directly into an era of convergence of the communication media. Another aspect, specific to Romania, and that is openly discussed is the excessive interference of the intelligent agencies in the mass media and in the political environment. Other visible consequences of the digital revolution are as follows:

- The information has become merchandise and the public is sold to the advertising agencies;

- The information is mixed with the commentary and they are presented as objective news. For that reason, it is more and more difficult, and even impossible, for the public to shape its own opinion; the public is forced to assimilate one opinion or another;

- Another consequence is that because of these information methods, the public is more biased than ever in the history of Romania. The fault lines of polarization are some of the most diverse: power/opposition, secret service/civil society, political right/left, supporters of the traditional family/supporters of LGBT, populists/democrats.

- The rules of journalism have changed. The classic rule of checking the information from three different sources was replaced by the rule of who delivers the information first. The check is done ongoing, after broadcasting, sometimes being necessary to deny the information. But the truth doesn't matter, only the effect: the traffic on the Internet is increasing, the audience is increasing, the number of comments at the end of the articles is increasing, because the polarization is reaching those comments, too, where there is no longer possible to have an unbiased opinion. You have to be on one side or another. Otherwise you are insulted, labelled, and socially marginalized.

- The digital technology favours the live broadcasting events that contain more emotions and less information. The journalists no longer write texts for reports, but for prompter, and those texts are real-time covered with inserts of images from the production-control room.

The mass media transformed itself fundamentally under the influence of digital technology. The function of the media to provide information has diminished under the pressure of competition, thus the information has become more and more some disposable merchandise. At the same time, the mass media has been more and more involved in new forms of warfare: information warfare, economic 
warfare, imagological warfare.

One of the most spectacular forms of information warfare through the mass media was the case of Cambridge Analytica, the British company that presumably helped Donald Trump win the presidential election in the United States. But the case of CambridgeAnalytica, of using media tools, social networks in shaping the public's "orientation", is not new:

"In 2012, Barack Obama's reelection campaign used a Facebook app to target users for outreach, giving supporters the option to share their friend lists with the campaign. These efforts, compared with those of Kogan and Cambridge Analytica, were relatively transparent, but users who never gave their consent had their information sucked up anyway. (Facebook has since changed its policies.) As the sociologist ZeynepTufekci has written, Facebook itself is a giant "surveillance machine": its business model demands that it gather as much data about its users as possible, then allow advertisers to exploit the information through a system so complex and opaque that misuse is almost guaranteed"(Chen 2018).

The data of millions of people extracted by Cambridge Analytica from Facebook was used in the election campaign in 2016, but also in the campaign after Brexit. Cambridge Analytica was investigated by both the American and the British authorities. The company was closed, but the method remains and it will probably be used also in some other information warfare.

This company's success is based on the researches developed by The Psychometrics Centre within the University of Cambridge (UK). These researches have focused on the study of the behaviour of the social network users. Thus, those involved in this study have developed an algorithm for monitoring and recording the "likes" given by the user on Facebook and, according to their distribution, the researchers were able to find out everything about the users, including for whom they would be voting in the next elections. For instance, considering three likes, one could find out the age of any Facebook user approximately by a year, as well as the person's gender and marital status. The IQ tests were the means through which the personal data of the Facebook users was extracted.

The economic warfare has different means of manifestation in the mass media. As a classic example in Romania, in 2007, there were broadcast some news in the media about the fact that Danone yoghurt had intoxicated several persons. The study of the press reports made by the students at the College of Communication and Public Relations within the National University of Political Studies and Public Administration revealed, in the end, that the media crisis was triggered by a company that wanted to enter the dairy market in Romania, where Danone was dominating the dairy market. Today, Danone holds a little bit over $50 \%$. This company generated a media crisis for Danone by broadcasting news that was never checked to the end.

\section{The Spanish Case with the So-called Catalan Process}

The case study refers to two situations, in Romania and in Spain. The Romanian case was intensively studied with the students at the College of Communication and Public Relations within some analyses that focused on the management of the image crises. The Spanish case was chosen because the author prepared partially her doctoral thesis at the National University of Political Studies and Public Administration, in Bucharest, and the other author taught for a week at the University of Girona, Spain, within the exchanges for the Erasmus + Programme of the European Union.

In Spain, the term "fake news" has become commonly used, even during political debate itself. Sometimes politicians have come to regard as false news a journalistic coverage that goes against their interests. One of the last examples is related with the new Spanish president, Pedro Sánchez, who in September 2018 called fake new accusations of plagiarism of his doctoral thesis. However, what has focused more attention is the information war linked to the so-called Catalan process. It is the political process by which the Catalan independence movement seeks that Catalonia becomes independent from Spain. For the moment its most controversial moment was on October 1, 2017, when Catalonia launched a referendum to ask about independence and the Spanish government responded with heavy loads by the police. Besides being a major event, that case fulfils a number of characteristics which make it fertile ground to propagate disinformation, as Coromina and Padilla state in an analysis edited in 2018 by the Catalan Audiovisual Council (CAC).

To obtain a sample of disinformation related to the referendum on October 1, Coromina and Padilla used the 52 news items refuted by the fact-checker MalditoBulo on its Twitter account (@malditobulo) thirty days before and thirty days after the date of the referendum: from $09 / 01 / 2017$ to $10 / 30 / 2017$. $67 \%$ of the items of disinformation (35) were part of the pro-independence narrative, whereas $33 \%$ (17) correspond to a pro-unity narrative. It seems that the independence movement more frequently used items of disinformation to support its discourse. That analysis states that $75 \%$ were covered by the media. However, the traditional media were much more effective at detecting and checking stories of disinformation that aim to benefit the independence movement.

Looking at the strategies used in constructing fake news, the study concluded that both sides used a repertoire of very similar resources. In both cases, almost half of stories of disinformation published were not attributed to any clear source. However, on five occasions there were actually 
public figures themselves (politicians, journalists, etc.) who originated the disinformation, suggesting that this type of actors plays a crucial role in the development of the narratives of the two extremes in conflict. The text was the preferred media format to spread stories of disinformation and the evidence suggests that it can be related to the fact that writing a text is easier than taking a photo or a video. Moreover a photo is easy to deny. As a conclusion, Coromina and Padilla state:

"Most of the items of disinformation published in the period under study had highly specific objectives: to link the independence movement with violence, exaggerate the police action on October 1, accuse the Spanishgovernment of waging a dirty war, overstate the number of people supporting each side and discredit the leaders of both movements".

As an example, on October 1, there was published an image on Twitter about a man with a bloody half-face used to prove the police brutality against the independence movement. The picture was accompanied by a text in which it is said that the person was injured in the neighbourhood of Gràcia (in Barcelona's city) by a rubber ball (of those who use the riot forces). However, the image corresponded to one of the injured during the police charges against the protests of the miners that took place in 2012 in Madrid. Among critics of Catalan independentists, on October 1 an image was shared showing a policeman shot in the ground that was hit by a group of crowded people. The photograph was real, but it had been taken in 2008 during a protest of farmers in the Andalusian province of Almeria.

Fake news has not been limited to the so-called Catalan process. One of the most relevant examples that certified this tendency occurred on January 24, 2013. The newspaper with the most diffusion in Spain, El Pais, was forced to withdraw from the kiosks the edition of that day and reprint a new one. The president of Venezuela, Hugo Chávez, suffered a cancer. His health was secret, but he knew he was being treated at a hospital in Cuba. El Pais had access to a picture where Chávez seemed to be intubated in the bed of a hospital. On the front page of the newspaper photograph appeared with the headline: "The secret of the Chávez disease".

In the text, El Pais claimed that the photo had been taken a few days ago and showed "a moment of the medical treatment in Cuba" received by Chavez, "according to the sources consulted by the newspaper". A few minutes after publishing the cover on the Internet, the newspaper found out through the social networks that the image was not of Chávez, but came from a video of 2008 about an operation to a patient without relation to the president. El Pais was a victim of false news and "committed one of the most flagrant errors in its history" (Amorós 2018). The newspaper offered explanations in an article published the following day. The article included a dialogue between the Deputy Director of the newspaper, Vicente Jiménez, and the director of photography, Luis Magán:

“- This agency will be trustworthy, right? - asked Jiménez.

- It seems to me that he is Chávez - Magán answered".

On August 17, 2017 there was a jihadist attack in Barcelona's famous La Rambla area where about 15 people died and there were dozens of injured. That terrorist action became a fertile ground for the rapid circulation of fake news through WhatsApp or Twitter, and some of them reached even the media. After the attack, media such as TV3, TVE, newspapers (The Independent) and digital ones (El Nacional or El Confidencial) informed that one or two terrorists had entrenched at a restaurant in La Rambla with hostages. Some media specified what type of weapons the terrorists carried, others said that the police negotiated with them and some came to detail the name of the restaurant (Amorós 2018). However, it was another fake new. The rapid dissemination of the news in spite of being false was possible for an increasingly common practice in the media: copying break news already published in other newspapers and publishing them almost as if they are made by themselves once it have been already released by a couple of media. In addition, they do that practise without contrasting the information with sources, at least initially, and sometimes without quoting from what media they have extracted the information. If there is something wrong, Internet makes easy to change whatever needed or even to delete an article.

Frequently fake news begin presented in a certain format, as a part of what is, or seems to be, the media, and contains all the signs of being from a reliable source (Corominaand Padilla 2018). One extreme example of the use of appearance to spread openly false content is the satirical publication El Mundo Today, which has often been confused (as its Anglo-Saxon peer, The Onion) with a serious publication.

\section{Internet, Fake News and the New Generation}

The study of the author Regina Marchi, dedicated to the teenagers and the way they inform themselves from the Internet, revealed a new type of media consumer's behaviour. Paradoxically, the teenagers prefer the information commented among friends, acquaintances, to the detriment of objective news: "With Facebook, Blogs, and Fake News, Teens Reject Journalistic "Objectivity" (Marchi 2012, 2-3). This phenomenon partly explains the vulnerability of the youngsters to fake news. The reason for this preference is obviously the dissatisfaction provided by the traditional media channels that are perceived as faking objectivity. For that reason, the young people prefer alternative information, with explanations, interpretations, eventually confirmed by friends, acquaintances who access them while they are working on the computer. The decline 
of the official channels' credibility, also known as "mainstream", created the possibility for the emergence of the alternative media. From here to fake news it was only one step.

The willingness to trust in news that are considered fake news is emphasized by the fact that young people find that the discrepancy between the image of the society as projected by the mass media and the reality they confront with every day is getting bigger and bigger; so, the bigger the gap, the bigger the openness to fake news. This phenomenon can be easily observed in the European Union, in the last general election in Italy. The success of the Five Star Movement political party was assured "by those who abstained from voting in the last election or by those who have never voted until now" (Digi24 2018).

\section{Conclusions}

Even if today fake news refers to false information broadcast through social networks, the fake news phenomenon is not new, as it appeared with the advent of the written press and in time it turned out to be a component of journalism. In general, any media channel newspapers, radio, television - aims to maximize the economic results, sometimes to the detriment of the information accuracy. What can be said about this phenomenon that was accelerated by the digital technology is that it began to undermine the news credibility after the media transformed itself too much into a business and distanced itself from its primary mission that is to inform. This phenomenon was written down under a more suggestive formula by an American editor: "The fight between the idealists and the accountants is now over. The idealists have lost" (see State of News Media Report 2006).

Fake news is for news what populism is for politics. Populism has never disappeared; it was latent, considered an eccentricity, in the periods of the highest economic development and political certainties. Populism resurfaces with a bang when people lose to a large extent their trust in authority figures and elite leaders. That is the case with fake news. It has never disappeared; it has been more or less extended, depending on the economic and political context.

The most serious consequence of the fake news phenomenon on the Internet is disinformation that gets inside the collective mind. People no longer take decisions based on authentic information. The emotional component is being stimulated, to the detriment of the rational decision, based on information and factual arguments.

The attenuation of the fake news phenomenon can be made through online and offline measures. The online measures can target the work algorithms, something that Facebook has already begun to do. The blocking can target also certain geographical areas, if this proves to be useful. Blocking and deleting some accounts are measures that need to be taken carefully, because they are essentially in contradiction to the American vision that promotes "a global, open Internet", in contradiction to China's vision that has promoted "cyber-sovereignty" as an organizing principle of Internet governance (Segal 2018).

An offline anti-fake news measure is possible in the legal field. The Internet needs to be treated as a public space, where the crimes, penalties and work procedures need to be very clearly defined in order to prove the respective accusations, and this component of justice needs to have international jurisdiction. This measure can be very useful because the juridical system can act as a filter, avoiding the abuses that inevitably appear in such situations, either on the users' side or on the authorities' side. The abuse of right is very well-known in Romania.

Another measure can be the return to the basic values of journalism, with a more prominent ethical component. But this component is always in competition with the necessity for bigger and bigger profit.

But the most important measure that can be taken against the proliferation of fake news is to understand why people are more willing now to accept fake news than several years ago and to take the necessary measures.

Some of the major difficulties to deal with fake news are to tackle rumours being shared on messaging apps and with the speed at which technology is refining the creation of fabricated video and audio. Wardle and Derakhshan (2017) propose thirty-four recommendations to face the challenges involving fake news. They address them to technology companies (such as create an international advisory council, provide transparent criteria for any algorithmic changes that down-rank content and build fact-checking and verification tools), national governments (regulate ad networks and require transparency around Facebook ads), media organisations (ensure strong ethical standards across all media and tell stories about the scale and threat posed by information disorder), civil society (educate the public about the threat of information disorder and act as honest brokers), education ministries (work internationally to create a standardized news literacy curriculum and update journalism school curricula) and funding bodies (support technological solutions and programs teaching people critical research and information skills). Above all of these recommendations, there is no doubt that there is to collaborate with each other to achieve a better informed world.

\section{REFERENCES}

[1] Amorós, M. (2018). Fake News. La verdad de lasnoticiasfalsas. Barcelona: Plataforma Editorial.

[2] Bounegru, L., Gray, J., Venturini, T. Mauri, M. (2017). A Field Guide to Fake News. Public Data Lab and First Draft. http://fakenews.publicdatalab.org. Accessed January 1, 
2018.

[3] Chen, A. (2018). Cambridge Analytica and our lives inside the surveillance. The New Yorker. https://www.newyorker. $\mathrm{com} / \mathrm{tech} /$ elements/cambridge-analytica-and-our-lives-insi de-the-surveillance-=machine?mbid=nl_Daily\%20032218 $\&$ CNDID $=49368860 \&$ spMailingID $=13174928 \&$ spUserID $=$ MTg2NDc2MDM0MzU3S0\&spJobID=1362062634\&sp ReportId=MTM2MjA2MjYzNAS2. Accessed March 21, 2018.

[4] Coromina, Ó. and Padilla, A. (2018). Analysis of disinformation regarding the referendum on 1 October detected by MalditoBulo. Quadernsdel CAC: Fake news, algorithms and filter bubbles (44), 15-24. https://www.cac.cat/en/documentacio/fake-news-algoryth ms-and-filter-bubbles. Accessed January 1, 2019.

[5] Kuklinski, J. H., Quirk, P. J., Jerit J., Schwieder, D, Rich, R. F. (2000). Misinformation and the Currency of Democratic Citizenship. The Journal of Politics 62(3), 790-816.

[6] Marchi, Regina. (2012). With Facebook, Blogs, and Fake News, Teens Reject Journalistic "Objectivity". Journal of Communication Inquiry XX(X), $1-17$.

[7] Polyakova, A, Boyer, S. (2018). The Future of Political Warfare: Russia, the West, and the Coming Age of Global Digital Competition. The New Geopolitics. Europe, BROOKINGS - ROBERT BOSCH FOUNDATION TRANSATLANTIC INITIATIVE. https://www.brookings.ed u/wp-content/uploads/2018/03/the-future-of-political-warf are.pdf. Accessed July 15, 2018.

[8] Revel, J.-F. (1993). Cunoaștereainutilă. Bucharest: Humanitas.

[9] Segal, A. (2018). When China Rules the Web. Technology in Service of the State. Foreign Affairs, September-October. https:/www.foreignaffairs.com/articles/china/2018-08-13/ when-china-rules-web?cid=nlc-fa_fatoday-20180821. Accessed August 23, 2018.

[10] Silverman, C. (2016). This Analysis Shows How Viral Fake Election News Stories Outperformed Real News on Facebook.https://www.buzzfeednews.com/article/craigsilv erman/viral-fake-election-news-outperformed-real-news-o n-facebook. Accessed January 1, 2019.

[11] Standage, T. (2017). The True History of Fake News. https://www.1843magazine.com/technology/rewind /the-true-history-of-fake-news.Accessed July 15, 2018.

[12] Vosoughi, S. Roy, D., Aral, S. (2018). The spread of true and false news online. Science (359), 1146-1151. doi: $10.1126 /$ science.aap9559.

[13] Wardle, C., Derakhshan, H. (2017). Information Disorder: Toward an interdisciplinary framework for research and policy making. Council of Europe Report DGI (2017)09. Brussels: Council of Europe. http://rm.coe.int/informationdisorder-toward-an-interdisciplinary-framework-for-resear c/168076277c. Accessed January 1, 2019.

[14] Wright, M. (2018). Social media giants using 'unethical' persuasion techniques to keep children hooked, psychologists warn. The Telegraph.https://www.telegraph. co.uk/news/2018/08/09/social-media-giants-using-unethica 1-persuasion-techniques-keep/?WT.mc_id=e_DM819953\& WT.tsrc $=$ email\&etype $=$ Edi_Tec_New_TechIntel\&utm_so urce=email\&utm medium=Edi Tec New TechIntel 201 8_08_10\&utm_campaign $=\mathrm{DM} 8 \overline{8} 1995 \overline{53}$. Accessed August $1 \overline{0}, 2018$.

[15] Wright, N. (2018). The Coming Competition between Digital Authoritarianism and Liberal Democracy. Foreign Affairs. https://www.foreignaffairs.com/articles/world/201 8-07-10/how-artificial-intelligence-will-reshape-global-ord er?cid=nlc-fa_fatoday-20180710. Accessed July 10, 2018.

[16] State of News Media Report. Project for Excellence in Journalism. (2006). Retrieved from http://assets.pewresear ch.org.s3.amazonaws.com/files/journalism/State-of-the-Ne ws-Media-Report-2006-FINAL.pdf. Accessed June 29, 2018.

[17] 4 casos de noticias falsas que intoxicaron el debate sobre la independencia de Cataluña de España. BBC Mundo. (2017). Retrieved from https://www.bbc.com/mundo/noticias-inter nacional-41703119. Accessed January 1, 2019.

[18] The real story of fake news. Merriam Webster. (2018). Retrieved from https://www.merriam-webster.com/wordsat-play/the-real-story-of-fake-news. Accessed July 18, 2018.

[19] Cum au ajunspartideleextremisteșiantisistemsăcucereascăv otulitalienilor. Digi24. (2018). Retrieved from https://www.digi24.ro/stiri/externe/alegeri-italia-2018-cum -au-ajuns-partidele-extremiste-si-antisistem-sa-cucereascavotul-italienilor-890038. Accessed August 10, 2018.

[20] A multi-dimensional approach to disinformation. Final Report of the High Level Expert Group on Fake News and Online Disinformation. European Commission. (2018). Retrieved fromhttps://blog.wan-ifra.org/sites/default/files /field blog entry file/HLEGReportonFakeNewsandOnlin eDisinformation.pdf. Accessed January 2, 2019. 